\title{
Independent Local Lists in Croatia: In Search for a Composite Theoretical Frame
}

\section{Ivan Kopric ${ }^{*}$}

\author{
UDK $352 / 353$ \\ Izvorni znanstveni rad (original scientific paper) \\ Primljeno 16.4.2007. \\ Prihvaceno 1.6.2007.
}

The paper deals with independent local lists in Croatia, in both analytic and theoretical way. At the beginning, the development and current state of local self-government and local political system in Croatia are described. Data on the independent local lists' participation and success during the 2005 general local elections are presented and analysed. Four theoretical approaches are proposed for an interpretation of the results: system, transition, neo-institutional and democratisation theory. None of them can alone explain the results in a satisfactory manner. That is reason why the author proposes a composite theoretical frame, which can explain the role and influence of a broader relevant context on the independent local lists' election success. Certain theoretical hypotheses are generated and

* Ivan Koprić, Ph. D., associate professor at the Chair of Administrative Science, Faculty of Law, University of Zagreb, and Dean of the Social Science Polytechnic in Zagreb, Croatia (izvanredni profesor na Katedri za upravnu znanost Pravnog fakulteta Sveučilišta u Zagrebu). 
to some extent verified in this paper. The advantages of the independent local lists and certain success factors of such lists are identified. Additional theoretical work and empirical verification are needed. Both qualitative insights and quantitative research can be useful.

Key words: independent local lists, local self-government - Croatia, local political system, local elections, composite theoretical frame (system, transition, neo-institutional, democratisation theory)

\section{Introduction $^{* *}$}

In the process of decentralisation of competences and financial decentralisation, local self-government system in Croatia is still dealing with the steps of institution development, as in many other transition countries.

Independent local lists continue to be the connecting point at the crossroads of local self-government system and political system of a country. Local self-government systems are comprised of at least two components ${ }^{1}$ - political and administrative. The political one is connected with the issues of local democracy, politics and public policies at local level. The administrative one is concerned with policy implementation, production of public services at local level, including communal utilities and social services, role of local self-government in the whole public administration system, etc.

However, the whole political system can be seen as comprised of several different but interconnected layers - central, regional, local, and so forth. It seems obvious that along with the political role of local self-government, there are others, and that besides local part there are other territorial levels in the whole political system.

What connects both systems - self-government and political - is their presumed orientation towards citizens. From this point, what prevails is the notion of localness, local self-government and local (part of) political system, with independent local lists in the focus. I will try to analyse independent local lists in Croatia having in mind the described integrative

\footnotetext{
** This article is adapted paper presented at the scientific workshop Independent Local Lists in Europe - A Comparative Perspective held at Martin-Luther-University Halle-Wittenberg, Halle (Saale) on 13-14 April 2007.
}

${ }^{1}$ Financial one can also be mentioned. 
point of localness. Because of that, it seems logical to begin the analysis with a brief overview of the local self-government system in Croatia.

After that, I will analyse local political system in more detail. Then, the focus will be on the main issue of independent local lists. At the end, I will try to propose and to outline a theoretical frame for generating additional hypotheses, continuation of research and explanation of results.

\section{Croquis of local self-government in Croatia: development and current state}

Croatian history of local self-government is rich, dynamic and can be traced back to ancient times. The towns in the coastal, Mediterranean area of the country have a particularly interesting and long history. Many of them had been founded even before the Roman Empire whose part they used to be. Contrary to that, local self-government forms in the continental part of the country were established mostly during the Middle- Ages.

Despite numerous and frequent changes of state arrangements, political systems and public institutions, Croatia managed to introduce a modern self-government in the 1870s, within the frame of the Austro-Hungarian Monarchy. Democratic content of the territorial self-government was quite narrow during the first part of the $20^{\text {th }}$ century, in the then new Yugoslav state (the so-called First Yugoslavia), mostly because of King Alexander's dictatorship and Serbian domination over the whole Yugoslavia. ${ }^{2}$ During the socialist Yugoslavia, self-management became part of the official ideology and a widespread practice with regard to territorial self-government, economic system, and political system. Self-management in socialist communes - local communities in Marxist form - had much in common with the autonomous processes of classical local self-government and direct democracy, but without multiparty competition. The whole system was strongly local-oriented, at least within the frame of each Yugoslav republic. Thus, at the end of the 1980s, Croatia inherited a very strong local level and relatively weak republic level, in terms of competences, finances, civil servants, etc. ${ }^{3}$

2 Details can be found in Lozina, 2004: 39-100; Hrženjak, 2004: 2-22; Čepulo, 2000; Perko-Šeparović and Hrženjak, 1982: 57-81.

${ }^{3}$ For more details see Kopric, 2003, pp. 183-187; see also Petak, 2006, pp. 85-87. 
The first multiparty democratic elections were held in May 1990, at both territorial levels, local (communes) and central (republic), ${ }^{4}$ within the frame of old, socialist institutions. That means, for example, that representative bodies in the communes and at the republic level (Sabor) were composed of three chambers; that there were plural votes (certain citizens had opportunity to vote two or even three times, for representatives in two or in three chambers), etc. ${ }^{5}$

These elections and their results served as a basis for speeding up the process of gaining independence from other Yugoslav republics. The first democratic Constitution was passed at the end of 1990 (Christmas Constitution). Croatia finally got international recognition at the very beginning of 1992. Although the Constitution guaranteed the right to local self-government, the basic Law on Local Self-Government and Administration was not passed until the end of 1992. Only after the Croatian Parliament (Sabor) had passed that Law and certain additional laws, Croatia began to construct a completely new system of local self-government. The new system of local self-government began to function in the first half of 1993.

The new system was quite centralised. It was only after parliamentary and presidential elections in the winter of 2000, formation and entrance into office of the left-wing coalition government, Constitutional Amendments of 2000 and $2001,{ }^{6}$ and the new Law on Local and Regional Self-Government of 2001, that Croatia entered decentralisation policy (Antić, 2002). Right-wing government elected at the end of 2003 has also proclaimed decentralisation policy and announced a few decentralisation steps. However, despite certain changes of legal regulation, there is no significant decentralisation in terms of competences and finances. Croatia has a kind of hesitating decentralisation and continues to be a highly centralised country (Koprić, 2007a).

At the beginning of the 1990s, Croatia was divided into approximately one hundred communes. The new territorial organization was two-tier,

4 The Republic of Croatia was at that time still part of Yugoslavia. There was no regional level at that time.

${ }^{5}$ Interesting research and theoretical approach about the first democratic elections can be found in Grdešić et al., 1991.

6 The Constitutional Amendments (2000 and 2001) have accepted the principles of subsidiarity and solidarity, widened the competences, redesigned counties as units of regional self-government, and granted forms of self-government below municipal level with legal entity. 
with communes (općina) and towns (grad) at the municipal level and counties (županija) at the second level. At the end of 1992, 418 communes were established as predominantly rural units, 68 towns as urban units, and 20 counties as second level units. The City of Zagreb had (and still has) legal status and competences of both first and second level units at the same time. Since then, the number of units at the municipal level has increased significantly, from 486 to $555(14.2 \%)$. The number of communes has reached 429 ( $2.6 \%$ increase), and the number of towns 126 (85.3\% increase). The share of inhabitants living in urban areas has increased from $54.3 \%$ to $69 \%$ during the period of $1992-2005 .{ }^{7}$ Croatia now consists of 555 local units and 20 counties, with special status of its capital, the City of Zagreb ${ }^{8}$ (see Appendix 1).

Three types of self-government units have different competences and general role in the governance system. ${ }^{9}$ It seems that two additional changes have happened in local governance system over the past fifteen years. First, between 1992 and 2001 the counties were supposed to serve as the middle tier of government and were intended to be administrative and self-government units at the same time, but their first and more important role was to be the units of deconcentrated state administration. They were rearranged as units of regional self-government by the Law on Local and Regional Self-Government of 2001, when they lost all competences with regard to deconcentrated state administration and got wider self-government competences (Koprić, 2007). Secondly, a new category of large towns was introduced by the amendments on that Law passed in 2005. There are fifteen towns with more than 35.000 inhabitants, without the City of Zagreb, which are considered to be large towns (Appendix 2).

It should be noted that the forms of self-government below municipal level have to be established within each local self-government unit. They can be established so as to encompass one settlement, a few smaller settlements, or even one part of a settlement. They can be established as territorial committees (mjesni odbori), town districts (gradski kotarevi), and city quarters (gradske cetvrti; only in the City of Zagreb). Originally considered as the forms of citizens' participation in local public affairs, they were

7 There are 3.065.473 inhabitants in towns, and 1.371 .987 in communes (total is 4.437.460). - Pavić, 2006: 228-229.

8 With the population of 779.145 , the City of Zagreb is the biggest local self-government unit in Croatia. 2007.

9 For more details see Ivanišević et al., 2001; Koprić, 2003; Koprić, 2003a; Koprić, 
granted legal entity during the 2001 decentralisation reform and acquired firmer political legitimacy.

\section{Local political system: legal regulation, processes and financing}

The main pillars of the local political system, the catalysts of local political processes, and the channels of citizens' influence on local affairs are representative bodies, commune and town councils (općinska i gradska vijeća), county assemblies (županijske skupštine) and the City Assembly (Gradska skupština) of the City of Zagreb. Since 2001, the forms of territorial self-government below municipal level have also had their representative bodies (vijeća) elected in the so-called territorial elections (mjesni izbori). The number of seats in the local and regional representative bodies has to be odd-numbered, it has to be decided by the statute of a self-government unit (its main general regulative act), and depends on the number of inhabitants. ${ }^{10}$ Among other things, these ranges have shown that citizen's vote is worth less in the urban than in the rural municipalities.

Local and regional councillors have four-year non-imperative mandates, which are not professional, of course. The representative bodies are competent to regulate all local affairs, within the frame of law. The main acts are statutes, but local budgets and certain other by-laws are considered equally important, at least in terms of the required council majority for the final decision on their passing. The sessions of representative bodies are public. Most decisions have been previously prepared by representative bodies' committees, which are preparatory bodies of local councils. The members of representative bodies elect the president and up to two vice-presidents among themselves.

There are two executive bodies in each local and regional unit - executive board (poglavarstvo) and an individual executive functionary who is at the same time president of the executive board (see also Augustinović-Pavičić,

${ }^{10}$ Municipal units with less than 3.000 inhabitants can have representative bodies consisting of 7-13 seats, municipalities with 3.001-10.000 inhabitants can have bodies of 9-15 seats, municipalities with 10.001-30.000 inhabitants can have bodies of 13-19 seats, towns with more of 30.000 inhabitants can have representative bodies of 19-35 members, county assemblies can consist of 31-51 seats, and the City Assembly of the City of Zagreb consists of 51 seats. The number of seats in the representative bodies of the forms of territorial self-government below municipal level is regulated by the municipal statutes. 
2002). Individual executive functionaries are commune mayors (općinski načelnici), town mayors (gradonačelnici), City Mayor (gradonačelnik) of the City of Zagreb, and county governors (župani). Real political power in local and regional units lies with executive bodies. The relationship between representative and executive bodies is more parliamentary-like. On the one hand, mayors, governors and executive boards are elected from the majority of a representative body, and are politically responsible to that body. ${ }^{11}$ On the other hand, when a representative body decides to cast a vote of no confidence against an individual executive functionary or against the whole executive board, it must elect a new mayor or governor in 30 days. If not, such a representative body will be dissolved, and new local elections will be held.

The professional component of local and regional governance systems is reserved for local civil servants employed by local administrative bodies, administrative offices and services (upravni odjeli i službe). There are more than 10.000 local civil servants and employees, paid from local budgets. Heads of administrative bodies are professionals, but since 2005, they can be elected as members of executive boards also.

After the first democratic elections of 1990, local elections were held four times, in 1993, 1997, 2001, and 2005. The electoral system was changed four times, before general local elections of 1993, 1997, 2001, and for the elections of 1995 which took place only in the City of Zagreb, Zagrebačka County and certain number of municipalities on the territory of Zagrebačka County. Only the last two local elections, in 2001 and 2005 , were held according to the same rules. It was mainly the very principle of representation that was changed.

In the 1990 elections, plurality electoral system (»winner-takes-it-all«) was applied, with competition of candidates. After that, a mixed system was developed, in which the share of proportional mandate calculation was increased. In the elections of 1993, one half of the members of each local representative body were elected in the election units, by plurality rule, and one half of them were elected by proportional representation from party or independent lists. Since then, the share of proportional representation increased to $3 / 4$ for the elections of 1995 , and to $3 / 4$ for the elections

11 Mayors and governors have to be previously elected as members of the representative bodies. Other members do not have to be elected as representative bodies' members. If they are, there is an incompatibility between the two positions and they have to be substituted by other candidates from the election lists. Heads of local administrative bodies and other citizens can also be chosen as executive boards' members. 
of 1997. The 2001 and 2005 elections were held with full application of the proportional representation principle, with competition of party and independent lists, ${ }^{12}$ without competition of individual candidates. Only the lists that gained more than $5 \%$ of votes could participate in the division of seats in representative bodies ( $5 \%$ threshold). The number of seats for each list was calculated by using D'Hondt's method.

A clear development line with regard to the local electoral system can be easily noticed, which leads to at least two conclusions. First, the shift to proportional elections indicates a tendency to open possibility for smaller political actors, both small parties and independent lists, to get involved in the institutional political life and to influence local political decision-making. Second, and somewhat confusing, one can speculate about a slight tendency to depersonalise local politics. Namely, in the proportional electoral system, due to their organisational, personnel, and financial advantages, political parties may acquire the dominant position over citizens who may organise themselves and form independent lists only for local elections. Additionally, citizens have to vote for the lists, not for individual candidates. And finally, the election threshold of $5 \%$ and D'Hondt's method are actually not in favour of small parties and independent lists. It looks like the creators of the electoral rules - and they certainly come from the biggest national political parties - are not in favour of personalisation of local politics.

This somehow opens the issue of the direct democracy and the forms of direct democracy at the local level. The Law on Local and Regional Self-Government provides for certain forms of direct democracy. These are referendum, consultative referendum, local citizens' meeting, citizens' initiative, and various forms of territorial self-government below municipal level. Generally speaking, they have been rarely used so far, but when used, they were efficient. They are not, as in most other countries, the main political channels of influence, nor the most important political in-

12 Independent local list, according to the Law on the Election of Members of the Representative Bodies of Local and Regional Self-Government Units, are those lists which are nominated by a group of voters themselves. There should be 100 voter signatures for a communal list, 150 for a town list, and 500 for a county list or for an independent list in the City of Zagreb in order for the list be legally valid. The number of such an independent list members should be the same as the number of members of a local representative body. Behind such a list there can be a civil society organization, a strong personality with his/her friends or family, a company, a group of citizens, party or non-party members, or someone else. However, the official name of the list should be sindependent communal / town / city 1 county list $\ll$. The name of the first member on a list is be added (for example, Independent Communal List of Plinio Cuccurin). 
stitutions. Rather, they serve as means of correcting the rough will of political elites who have lead the processes of local political decision-making through local executive and representative bodies. From that aspect, their very presence, not practical usage, is very important for the relaxation of the political system (see also Almond and Verba, 2000: 349 and subsequent).

Certain other institutions have also served to the same purpose. These are the representatives of national minorities in local representative bodies, special minority councils and minority representatives with consultative and general supervisory competences, and youth councils with consultative role in local politics.

The Constitutional Law on the Rights of National Minorities of 2002 provides for the presence of national minorities' representatives in each local and regional unit where certain national minority has a minimum $5 \%$ share of inhabitants. If the share is between 5 and $15 \%$, the Law requires at least one national minority representative. If the share is above $15 \%$, there has to be just the proportional share of national minority representatives in a local representative body. ${ }^{13}$ If a minority is underrepresented after elections, the number of local representative body members rises for the necessary number and new members enter the representative body from the competing local lists, according to the election success. If that solution cannot resolve the problem of representation, additional elections will be held (Art. 20). Every local and regional unit is allowed to increase the number of national minority representatives autonomously

13 The Serb minority is the biggest national minority in Croatia. The share of that minority in the population is the highest in Vukovarsko-srijemska County (15.5\%). Its presence in other counties is as follows: $11.7 \%$ in Sisačko-moslavačka county, $11.5 \%$ in Ličko-senjska county, $11 \%$ in Karlovačka county, $9.1 \%$ in Šibensko-kninska County, $8.7 \%$ in Osječko-baranjska County, 7.1\% in Bjelovarsko-bilogorska and in Virovitičko-podravska Counties, and $6.5 \%$ in Požeško-slavonska County. Italian minority reaches $6.9 \%$ in the population of Istarska County. The presence of other national minorities is more dottedlike. There is Hungarian minority in certain units on the territory of Osječko-baranjska and Vukovarsko-srijemska Counties. There are $40.9 \%$ of the Hungarians in the population of the Commune of Kneževi Vinogradi, $35.1 \%$ in the Commune of Bilje, $26 \%$ in the Commune of Draž, $21.6 \%$ in the Commune of Ernestinovo, $18 \%$ in the Commune of Tordinci, $14.4 \%$ in the Commune of Petlovac, etc. The biggest Chech minority is on the territory of Bjelovarsko-bilogorska County, precisely in the Communes of Končanica (46.7\%) and Dežanovac (23.5\%), and in the towns of Daruvar (18.9\%) and Grubišno Polje (18\%). The presence of the Romanies is the biggest on the territory of Medimurska County, especially in the Communes of Orehovica (8.6\%) and Mala Subotica (7.6\%). Other represented national minorities are the Bosnians, Albanians, and Slovenians in certain parts of the country - Hrženjak, 2004: 42-148. 
above the mentioned share, but only if it is not the unit in which a national minority has the majority share of population (Art. 21). National minority representation has to be ensured in local executive and administrative bodies as well (Art. 22).

The same Law has provided for the whole network of separate, special national minority councils and representatives. A national minority council can be established by those minorities which have a share in local population over $1.5 \%$, or which have at least 200 national minority members in a local unit, or 500 members in a regional unit. National minority councils consist of 10 members in the communes, 15 members in the towns and 25 members in the counties. In the local and regional units which do not have the mentioned preconditions for the establishment of national minority councils, any national minority with at least 100 members can elect its own individual representative. The mandate of the councils and representatives lasts four years. The main role of both national minority councils and representatives is to participate in local public life and management of local affairs. They can participate through proposals, information sharing, consultations, supervision, etc. The legal status of these councils is the status of non-profit legal entities. The main sources of national minority councils' and representatives' finances are local, regional and state budgets. Additionally, at least two national minority councils can establish a coordination of national minority councils and make their position much stronger through such networking (Articles 23-34).

The recent Law on Youth Councils of 2007 has provided for similar local consultative mechanism on behalf of young people. However, the initiative for establishing youth councils does not depend on the will of represented citizens, as is the case with the national minority councils and representatives. Youth councils should be established by local representative bodies themselves, as their consultative bodies, with the purpose to attract young people to participate in local public life. ${ }^{14}$ Individuals between 15 and 29 years of age are considered to be young people. The number of youth council members can be between 5 and 15, depends on the size of local population, and should be odd-numbered. The mandate of youth representatives lasts two years. Finances and premises for youth

${ }^{14}$ One recent research in Croatia has shown that only $56 \%$ of the young (secondary school) generation sees democratic political system as a desirable solution (Vujčic, 2006). It seems somewhat disturbing and requires designing an appropriate democratic education for young generations. Including young people into local politics could be one practical aspect of such an education. 
councils should be ensured by local and regional units. The Law requires the establishment of youth councils before $9^{\text {th }}$ September 2007.

Proportional election system, as a rule, leads to a greater political fragmentation and heterogeneity in representative bodies, which can cause the instability of executive bodies. It is hard to elect executive functionaries and boards in such conditions, and the chances for voting no confidence are real and great. Practically each vote in a representative body is important and that is a basis for all kinds of unethical behaviour of local councillors. In certain recent cases, parties or the representatives of lists with only one or two votes asked, and what is more, succeed in getting the positions of mayors, presidents of local representative bodies, other influential positions or lucrative jobs in communal services or communal utility companies, etc.

Such unethical behaviour has speeded up the ongoing discussion about the appropriate institutional solutions. Direct elections of town and commune mayors and county governors were proposed as the main solution some five years ago. Almost all political parties, associations of local and regional self-government units, influential NGOs and other stakeholders have formed a policy coalition about the introduction of such elections. A minority of experts and university professors are also in favour of that solution (Podolnjak, 2005), but the majority of them have been warning and raising questions about the potential risks of such a solution (see Koprić, 2005; Sokol, 2006: 3; see also Larsen, 2002). Draft Law on Direct Elections of Commune and Town Mayors and County Governors was prepared and entered the legislative procedure in July 2005 as a Government's proposal. The shift towards the election of mayors and fundamental change in the functioning of local political system from parliamentary-like to presidential-like is being prepared for the local elections of 2009 and the period after that. The Law has not been passed yet, although it is undergoing the legislative procedure.

Another attempt to solve the problem of unethical political behaviour deals with the way of financing political actors. The new Law on the Financing of Political Parties, Independent Lists and Candidates was passed at the very beginning of 2007. The Law intends to ensure transparency in financing the political actors, efficient financial control, preventing certain subjects from financing the political actors, limitation of donations, ${ }^{15}$

15 An individual is allowed to give up to $90.000 \mathrm{HRK}$ (about $€ 12.169$ ) per year to a particular political party or independent list. A legal entity can give up to $1.000 .000 \mathrm{HRK}$ (about $€ 135.135$ ) per year to a particular political party or independent list (Art. 4). 
interdiction of receiving donations from anonymous subjects, interdiction of the usage of public assets and funds for private purposes, etc. The Law contains new, stricter rules of financial support to political parties and members of representative bodies from independent lists at all levels. ${ }^{16}$ However, the Law does not contain all important safeguarding mechanisms, which have been proposed during the previous public and professional discussion (Jelušić, 2007).

The Law is applied to the independent lists, also. The leaders of independent lists are obliged to open an account for election campaign expenses. Elected independent lists' members have the right to get regular financial aid for their representative activities from the respective budgets (local, regional, or central). They can have their offices for administrative and professional support with their own employees (Art. 26).

\section{Independent local lists: Scyllas and Haribdas of local politics}

The role of local independent lists can be conceptualised in many ways. Somewhat fancy interpretation during and immediately after the last general local elections of 2005 was connected with the criticism of political parties and unethical behaviour of (local) politicians. Previous general local elections of 2001 were also held with the application of the proportional election system, thus generating the fragmentation of local political scene and pushing political actors to all kinds of coalitions necessary for the formation of the executive bodies (Omejec, 2002). Public perception of local politics and governance systems was somewhat weak.

One of the bad examples was related to the City of Zagreb. Two left-wing parties, Social Democratic Party (SDP) and People's Party (HNS), formed

16 The total sum of money for political parties and independent members should be calculated so as to amount $0.056 \%$ of total budget expenses in the respective unit for previous year. The total sum is divided with the total number of representative body members and should be paid to the political parties and independent members (members elected from the independent lists). The amount is raised $10 \%$ for every female member. Political parties have been getting sums which depend on their member share in a representative body. Representative bodies' members elected from the independent lists have been getting money on their special bank accounts. To prevent the after-election fragmentation and manipulations with budget money, it is stipulated that after-election changes in party membership as a rule cannot change financial support sums that have once been determined on the basis of election results (Articles 7-13). 
a coalition, having 32 of 51 seats. Certain concrete circumstances caused disharmony, sometimes even a conflict between the coalition partners. Having in mind that the City of Zagreb is the greatest, economically and in other ways the most important local unit in Croatia, it is not hard to imagine that disharmony in the ruling coalition was an everyday media and public topic. With some other examples, this significantly contributed to voters' negative impressions about local politics. However, this caused only a slight increase of the share of independent lists' seats in the City of Zagreb Assembly after the 2005 elections, from 9.8 to $13.7 \%$ (see Appendix 8 ). Nevertheless, changes in the share of seats of certain political parties were substantial (Ivanišević, 2006).

The results of the so-called territorial elections for the city quarters' councils in the City of Zagreb show a situation very similar to the situation with the City Assembly. There were two such elections, in the years 2000 and 2005. Independent lists managed to win only 9 out of 283 seats in the city quarters' councils or $3.2 \%$ of the total number of council seats in the 2000 elections. The result of the independent lists was a bit better four and a half years later. They won 12 out of 271 council seats, or $4.4 \%$ of the total number of seats in city quarters councils (Appendix 7).

Such a situation leads to a two-fold hypothesis. First, it might be that urban units for some reasons are not a suitable scene for independent lists. Second, it is possible that bigger units do not provide suitable conditions for the success of local independent lists.

Croatian data on 2005 general local elections could be used to support both hypotheses (Appendixes 3 and 4). There were 397 independent lists in competition for the seats in the communes' councils. It counts for $65.3 \%$ of all the competing lists ( 608 of them). In contrast, there were only 194 lists in the towns, including the City of Zagreb, which count for $31.9 \%$ of the total number of the independent local lists. Only 17 independent lists competed at the county level (2.8\%).

Additionally, as much as $77.1 \%$ of independent lists in the communes were successful (306 of 397), compared with only $49 \%$ of such lists in the towns (95 of 194). Successful independent lists in the communes won 629 seats or $73.8 \%$ of the total number of seats that were won by all independent lists. Only 202 seats were won by independent lists in the towns $(23.7 \%)$. Although the average number of seats that were won by independent lists is the same for independent lists in the communes and in the towns (2.1), it should be noted that the number of seats in communes is smaller in average, according to their smaller number of inhabitants and legal frames of local councils' size. It can be noted that there are $12 \mathrm{com}-$ 
munes with 1.900 inhabitants in average, and only one town among the most successful examples, i.e. local units in which independent lists won the elections (Appendix 5). Finally, taking into account the number of inhabitants, it could be calculated that there are 629 representatives from independent lists on 1.371.987 inhabitants of all communes, which gives the ratio of 1 representative on 2.181 inhabitants, while in towns that ratio is 1 representative on 15.176 inhabitants $(202: 3.065 .473)$.

What could be the reasons for such a state of affairs? Part of the possible explanation lies in the nature of two kinds of local units. In rural communities there are many concrete problems which are mainly not in the focus of big national political parties, not even the regional ones. After that, personal profile of local politicians can be the most important in communes as in average significantly smaller communities. ${ }^{17}$ It seems that the programme profile and other characteristics of the political parties can influence voters in local elections, especially in smaller units, only to a limited extent. A hypothesis can probably be formulated which says that the chances for the success of independent lists are proportionally higher as number of inhabitants in a local unit decreases. With regard to this, it can be noted that 12 communes where independent lists won the elections have significantly smaller average population than the average population of a Croatian commune (1.900 vs. 3.221).

One organisational reason seems to be practically important also: only a few political parties have their branches in smaller communes. Political parties are mostly interested in acquiring political support in towns, because of the simple fact that a significantly larger number of people lives there. The overall penetration of political parties is lesser in smaller units, and stronger in larger units, as a rule. Because of that, there is less space for independent lists in the larger units, i.e. towns (see also Kasapović, 2004).

Of course, this argument is in a way connected with the situation in the whole political and social system. If the political system is not very stable, many changes in the structure of political parties can be predicted, problems with building parties' organisational apparatus, lesser penetration, etc. If there is a dense network of NGOs and stronger civil society, which is mainly not a characteristic of rural municipalities, there is greater space

17 As much as 242 or $56.8 \%$ of communes have less than 3.000 inhabitants, while additional 117 or $27.5 \%$ have between 3.000 and 5.000 inhabitants. Only 67 or $15.7 \%$ of communes have more than 5.000 inhabitants. As of 2004, average population in communes is 3.221, while in towns it reaches 18.588. - Pavic, 2006. 
to express specific interests of local communities through the independent lists which are led by strong local personalities. Apart from that, towns give such a social and institutional environment where one can professionalize his/her political activity as a real job, while in the rural areas almost all politicians are predominantly engaged with some other, mostly agricultural or similar activity. ${ }^{18}$

Differentiation of citizens' interests and generally higher overall living standard in the towns are favourable conditions for both, stabilisation of political parties and civil society development. In towns, there is a better offer of various political parties' programmes. Civil society is able to absorb a wide variety of public interests, also. So, there is less need to search for something else.

Besides, towns are not a suitable environment for the success of strong personalities. Behind each independent list there is a strong personality. ${ }^{19}$ Towns are highly stratified communities, with a lot of well-known and successful people, with many professionals of all kinds, with better economic situation and better communal infrastructure, with denser institution network, with much greater number of voters, etc. In such a situation, it is not an easy task to build one's media and overall public image which would ensure the possibility to gain seat(s) in local council. Chances to win local elections are even slighter.

The data on the number of independent lists and their success in rural and urban municipalities show a great difference and tentatively confirm

18 In the well-known example of Mošćenička Draga, the major who has won several subsequent mandates with his independent list is at the same time a fisherman. His list won 5 of 9 seats in the last elections of 2005.

${ }^{19}$ For example, the independent list which succeeded in gaining 4 seats in the Town Council of Split is led by the former well-known basketball player Željko Jerkov, who has been a very successful businessman for some time. In the City of Zagreb Assembly 4 seats were gained by the independent list led by Tatjana Holjevac, daughter of one of the most popular City Mayors ever, Većeslav Holjevac. In the City of Zagreb Assembly 3 seats were won by the independent list of Boris Mikšić, the man who returned from the USA with rather fuzzy curriculum vitae, with snob-like manners, pretending to be successful businessman. The independent list led by Plinio Cuccurin won in the Commune of Bale Council. Cuccurin is very well-known member of the Board of Directors in the biggest tobacco company in the region. Stipo Gabric, considered as one of the rich tycoons (persons who have suddenly succeed in becoming rich during the non-transparent privatisation of the former so-called social ownership under suspicious circumstances) and one of the best-known dissidents from the long time leading Croatian political party, HDZ (Croatian Democratic Community), led victorious independent list in the Town of Metkovic (11 of 17 seats; 64.7\%) and the successful independent list for County Assembly of the Dubrovačko-neretvanska County ( 7 of 41 seats; $17.1 \%$ ). Etc. 
the described way of thinking. Independent lists were competing in many more towns than in communes, reaching $76.6 \%$ of the total number of towns during last general local elections of 2005. At the same time, independent list were competing in only $57.7 \%$ of the total number of communes. These data probably indicate more intensive political interest, or interest to participate in local politics in urban units. However, the success of independent local lists was significantly lower only in the urban units, as has been mentioned (the ratio between towns and communes is $49 \%$ : $77.1 \%$ of successful independent lists). That confirms the thesis that the chances to succeed with an independent list in the towns are generally much smaller, probably because of different nature of local communities and because of their size.

The problem with independent lists' participation in the elections for county assemblies is easier to notice. ${ }^{20}$ The counties are relatively new units, with role and competences that have been changing (more in Kopric, 2007). They are not sufficiently rooted in historical and wider social context. It is hard to expect them to be homogeneous with regard to citizens' interests, or to become points of regional identification. Finally, they are much bigger than towns. In that way again, the size of election units seems to be significant. So, independent lists can hardly succeed in the elections at the county level. The results of 2005 elections support that conclusion. The share of unsuccessful independent lists is very high (88.2\%). Only two independent lists at the county level succeeded in gaining seats and both cases have an interesting context.

In Dubrovačko-neretvanska County the independent list led by Stipo Gabrić gained 7 of 41 seats and became an important political actor in the County Assembly. Although his political attitudes could be considered rather conservative, he entered into coalition with left-wing parties, mostly because he did not want to form a coalition with the HDZ. He is a dissident from that party, he was accused of privatisation crimes by his previous party colleagues, and the intensity of the conflict between him and the HDZ was obviously so high that it prevented him from joining the coalition with his former cronies.

${ }^{20}$ During its history, Croatia usually had the second tier of government, but with different roles, competences, number of units, etc. Counties as part of the common Hungarian and Croatian heritage were re-established in the early 1990s. However, they are of relativelly small size, with average size of 2.800 square kilometres and 183.000 inhabitants (the City of Zagreb excluded). They have not been formed with respect to historical Croatian regions such as Slavonia or Dalmatia. Political needs and respects have overwhelmed historical, social, legal and technical criteria of county mapping (see also Antulov, 2000: 6). 
The case with the independent list of Branimir Glavaš in Osječko-baranjska County has certain similarities with the previously described case, but also a few essential differences. Glavaš was one of the most influential members of the ruling party, the HDZ, with seemingly impressive but somewhat murky war record. Some time before the general local elections of 2005, he split from his party's mainstream and suddenly started to promote regionalism, which was quite strange. He argued that Slavonia, one of the three historic Croatian regions, ${ }^{21}$ was receiving too little attention and funds from the State Budget. His conflict with his former party was very intensive. As there was certain number of the highest state servants and state functionaries under his strong influence, he managed to gather many of them in an attempt to establish a new political party before general local elections. However, he did not succeed and had to compete with local lists only. His success was significant. His independent county list gained 14 of 47 or $29.8 \%$ of the seats in the County Assembly of Osječko-baranjska County. In Osijek Town Council he gained even more, 8 of 25 or $32 \%$ of the seats. After the elections he entered into coalitions with the ultra (far) right-wing Croatian Party of Rights (HSP). He also succeeded in establishing a new political party, the Croatian Democratic Party of Slavonia and Baranja (HDSSB), regional, according to its name, with aspirations to widen its influence throughout Slavonia. ${ }^{22}$

Both cases have shown that the situation that can help certain independent list to succeed in units such as Croatian counties has to be very strong and specific. The data on the success of independent lists at both local and county levels show that the chances to succeed are going to diminish at every wider level of the governance system. Data on the results of independent lists at the national level are going in the same direction - not one independent list was successful in the parliamentary elections of 2000 and 2003 (Kasapović, 2004: 85). ${ }^{23}$

${ }^{21}$ Croatia used to be considered a three-part state (Croatia, Slavonia and Dalmatia) since the Middle Ages.

22 It includes five counties: Osječko-baranjska, Vukovarsko-srijemska, Požeško-slavonska, Virovitičko-podravska, and Brodsko-posavska.

${ }^{23}$ There were 57 independent lists in the parliamentary elections of 2003 , all unsuccessful (Kasapović, 2004: 85). In previous parliamentary elections there were a few independent members in Croatian Parliament (Sabor), because of at least partial usage of the plurality rule (»winner-takes-it-all ). Their number was $1(1.25 \%)$ in the 1990 elections, 5 $(3.62 \%)$ in the elections of $1992,4(3.15 \%)$ in the elections of 1995 , and $3(1.99 \%)$ in the elections of 2000 (Čular i Blanuša, 2001: 229). 
Both described cases have also led to the questions about the independence of local lists. What kind of independence, whose independence, independence from whom, how much independence, are but a few of such questions. However, before that, two more circumstances should be taken into account - regional differences in popularity of independent local lists, and the role of independent lists in minority issues.

Regional differences in the presence of independent local lists are quite noticeable. Three main observations can be made. Independent local lists were competing during the elections of 2005 in 354 of 570 , or $62.1 \%$ of local and regional units. In some parts of the country, independent lists were significantly more widespread than in others. On the one end of the continuum there were coastal counties, led by Zadarska County. Independent lists were competing in $84.8 \%$ of local units on the territory of Zadarska County ( 28 of 33 ). On the second place was Istarska County with independent lists in $79.5 \%$ of local units (31 of 39), Splitsko-dalmatinska County was on the fourth place with such lists in $78.2 \%$ of local units (43 of 55), and Primorsko-goranska County on the sixth with independent lists in $74.3 \%$ of units ( 26 of 35 ). Although additional research on that topic would be needed, one can speculate that stronger interest in local politics is connected with the Mediterranean region, which has a long history of local self-government. It should be noted that parts of Croatia, especially parts of Splitsko-dalmatinska County, have historical ties with ancient Greece and with historical roots of Greek democracy. Certain other parts, also mainly in the coastal region, have had very clear developmental paths since the ancient times (Roman Empire, for example) or since the Middle Ages, probably possessing historical reminiscences on the then strong and wide town autonomy. Such reminiscences are probably good ground for stronger interest in local politics. ${ }^{24}$

On the other end of the continuum of independent lists' presence were Varaždinska County, with such lists in as little as $17.9 \%$ of local units $(5$ of 28 ), and Bjelovarsko-bilogorska County (21.7\%; independent lists in only 5 of 23 local units). These extremes are not easy to interpret, but it seems that the offer of political party lists or candidates on those lists was much better and much widely accepted than in other parts of the country. Since political parties managed to acquire strong support, there was no

${ }^{24}$ In 2001 general local elections there was a similar pattern of the independent local lists participation. In the six coastal counties independent lists competed in $62.9 \%$ of local units, while in the continental part of the country independent lists competed in $54 \%$ of local units (Kasapović, 2004: 87-88). 
space for independent lists. In Varaždinska County, there is one of the main footholds of the Croatian People's Party (HNS) while in the county seat, the Town of Varaždin, there is a strong and stable political support for the Croatian Socio-Liberal Party (HSLS), mainly because of its town mayor and list holder in the Town of Varaždin. In Bjelovarsko-bilogorska County the situation is different in the county seat, the Town of Bjelovar, where Socio-Liberals have very strong support and in other local units where the Croatian Peasants' Party has a significant influence. However, there is a similar situation in other parts of the country as well. This is the reason why other variables have to be introduced and researched. It may be that a different, more co-operative, political culture has been developing, or that the core local goals have already been identified, which allows for reducing the intensity of local political conflicts, etc. It should be concluded that surprisingly weaker presence of independent lists in certain parts of the country has to attract additional research attention.

Stronger presence of independent lists in some parts of the country can be explained by some very specific reasons. Such is the situation, for example, in Osječko-baranjska County, where a new party, the Croatian Democratic Party of Slavonia and Baranja (HDSSB), was in the forming phase during the local elections of 2005. This party in statu nascendi was in a way hiding behind the independent lists.

Stronger presence of independent lists in Sisarko-moslavačka County was a little surprising (independent lists in 15 of 19 , i.e. in $78.9 \%$ of local units, which is third best result). Two main ideas can be mentioned. First, Sisak used to be and still is an industrial town, and such are some other towns in the County (Kutina, even Petrinja), but the main industrial branches, chemical industry and iron and steel industry, are in crisis. It might be that industrial workers and trade unions culture call for more robust, more intensive and anti-party engagement in attempts to resolve big social and local problems.

Nevertheless, it should be noted that a major part of that county was engulfed by the war and the Serb minority rebellion (1991-1996). In ten years that elapsed between the censuses of 1991 and 2001, Sisačko-moslavačka County was faced with an enormous depopulation and changes in the population structure. The number of inhabitants decreased from 286.914 to 185.387 (depopulation of $35.4 \%$ ), and the share of the Serb minority fell from $34.5 \%$ to $11.7 \%$ (Hrženjak, 2004: 103). In a situation with many unresolved after-war problems, it can be logically expected that the Serb minority is trying to find an alternative political way to gain positions in local representative bodies through independent lists, and not through 
political parties with national labels. The same is true for the Croatian minority in certain other local units. ${ }^{25}$

It strongly raises the issue of minorities in discussion about independent local lists. The idea about hiding behind independent lists seems especially plausible in the conditions of unconsolidated inter-ethnic relations in certain parts of Croatia, ${ }^{26}$ but it calls for additional research.

However, even in normal conditions, it seems that richer national minority structure can stimulate the forming of independent local lists. ${ }^{27}$ In a dotted pattern of the national minority territorial structure, an independent list can acquire an image separated and different from political parties' images, especially from big national parties; as well as the feeling of self-determination and self-confirmation, so precious for national minorities (Schöpflin, 2001: 16). ${ }^{28}$

\section{Independence in composite theoretical frame}

Previous rather descriptive and narrative analysis based on meagre empirical data at the end provokes deeper theoretical questions and calls for theoretical explanations. Firstly, there are the questions about independence and the circumstances which stimulate or de-stimulate the presence and success of independent lists in the elections for local representative bodies. Secondly, there are the questions about deeper theoretical frame. Such a frame might lead to the identification of new explanations, to the evaluation of possible explanations, and to putting the already accepted and verified explanations in a new light. In other words, a theoretical frame should help to generate, specify and evaluate the hypotheses about independent local lists, systematize them and, in such a way, form a theoretical basis appropriate for (further) empirical research.

25 In Sisačko-moslavačka County there are two communes with the Serb majority and the Croatian minority. In Dvor there are 3.495 Serbs and 1.943 Croats, while in Grozd the ratio is 2.193: 1.500 (Hrženjak, 2004: 103).

26 There still persists a rather deep cleavage between Croatian and Serb communities. The worst is probably the case of Vukovar. See, for example, Gosselin, 2004.

${ }^{27}$ A good illustration can be found in the Commune of Kneževi Vinogradi (Osječkobaranjska County), with independent list of the Hungarian minority. See case study of $\triangle$ urić, 2004: 89.

${ }^{28}$ See, for example, rich reviews in Bíró and Kovács, 2001; Gál, 2002. 
In my opinion, a composite theoretical frame can be employed to achieve the mentioned results. It should consist of system theory, transition theory, neo-institutional theory, and democratisation theory, at least in transition countries.

The system theory offers three main views which see social systems as (1) closed systems, consisting of relatively autonomous elements integrated in the wholeness by certain basic principles, (2) open systems, characterised by dynamic and complex relations, interdependence and exchange with different segments of system environment, and (3) self-referential systems, in which human conscience serves as a mechanism of self-observation, self-identification, self-reference and autopoiesis. ${ }^{29}$

Although the system theory could seem too general, it may warn about the questions about the wholeness and parts of a political system, their characteristics, relevant system environment, the relationships among parts within a system, and the relationships between the system and environment and their characteristics, etc. Of course, these questions should be applied to the political system in general, as well as to particular national political systems. More concretely, and having in mind independent local lists, there are the following questions about:

- fragmentation, consolidation, and stabilisation of the political system, and influence of independent lists on these characteristics,

- nature of independent local lists and their function in the whole political system,

- reasons from political and broader societal environment which cause the presence and success of independent local lists (for example, forms of direct democracy, political party system, structure and relationships between local units' bodies, channels of political accountability, legal regulation, density and quality of civil society, political and social culture, ethics in political system, etc).

In an attempt to answer these and similar questions, the transition theory should be taken into account, also. ${ }^{30}$ There are many various notions of

29 Credits for this insight should be given mainly to Niklas Luhmann. See, for example, Pusić, 1989: 61-62. About the concept of autopoiesis and its usage in different fields, including organisation and social systems, with critics on the Luhmann's contribution, see Mingers, 1995.

30 In such a way Lewis argues: »In view of the short time that has elapsed since 1989 and the wide-ranging nature of the transformation that has occurred since then CE party systems are, understandably, less consolidated and less well defined than is the case with more established EU Member States.« - Lewis, 2004: 252-253. 
the last large transition, the transition from previous socialist systems with command economy to the democratic systems with market economy. Marčetić has recently described eight of them, but, certainly, additional notions of transition might be established or developed (Marčetić, 2005: 7-48). Post-socialist transition can be considered as a complex systemic transformation different from the previous democratic transitions in Southern Europe (Spain, Portugal), Latin America, and certain other parts of the world. The main difference is connected with the span of transition processes: previous transitions can be mainly considered as democratisation, tackling the political systems. Post-socialist transition is more complex and comprehensive, a systemic one, tackling almost every aspect of social life. If such a concept is taken as acceptable and the most productive, there is obvious need to put the discussion about independent local lists in a much broader context, and in the context of dynamic processes of overall transition.

Two main additional issues are raised and stimulated by transition theory, with regard to the broader context of independent local lists. First, there is the issue of stabilisation and consolidation of a new democratic political system, but that issue has already been raised by the system theory, although in a more general manner. Second, and more important issue from the standpoint of the theory development, is concerned with design, building and development of the new institutions in transitional context in Eastern, Central and South-Eastern Europe.

New institutionalism is a very common and widespread theoretical frame (see, for example, Marčetić, 2006: 8-36). It warns about the significance of institutions and the rules, as March and Olsen have recently said: »Political institutions and rules matter. Most people in politics and political institutions follow rules most of the time if they can ... Rules and understandings frame thought, shape behaviour, and constrain interpretation.« (March and Olsen, 1995: 31). However, the design of new institutions is somewhat uncertain, in a way $\gg$ that designers of new institutions are often writing on water (Putnam, 1993: 17). In other words, broader societal context, culture and other factors should be taken into account. ${ }^{31}$ Finally, rules are product of societal context and live and function in societal con-

${ }^{31}$ Wollman claims that several factors should be taken into consideration in explaining the cross-country variance of the public sector reform trajectories: socio-economic context, institutional and cultural tradition and "path dependencies«, institutional setting (polity), constellation of relevant political and socio-economic actors, reform coalition, starting conditions. - Wollman, 2001: 15-16. 
text. Just knowing the rules is not enough; research on real life of rules (on independent local lists and other issues of local political system, for example) in society is a much more productive approach. Another aspect of institutional approach, which can be named »historical-institutionalist approach« (Wollmann, 2000), has been searching for identification of different phases in the institution building. Such an approach can show transition as a chain of institutional choices and sequence of phases in developing certain institutions, including independent local lists.

Finally, there is obvious need for inclusion of the democratisation theory into the composite theoretical frame. It seems that there is no unitary democratisation theory, nor unitary theory of democracy. Even the definition of democracy is not easy to find. March and Olsen are considering four parts or components of democracy:

- »a commitment to personal liberty and individual responsibility in its exercise«,

- »the idea of popular sovereignty and political equality«,

- sfaith in the role of individual and collective human reason in human affairs $\ll$, and

- »an emphasis on procedural reliability and stability, on the rule of law and the regulation of arbitrary power (March and Olsen, 1995: 2-3). ${ }^{32}$

However, a closer look can open issues of plural society in which the situation is more complex and precarious, with a lot of preconditions for stable democracy. Many post-socialist societies can be considered plural and may require more complex thinking about democratisation. At least some of them need to understand and build consociational democracy, i.e. a political system characterised by a great coalition of all the important segments: leaders, a kind of veto in the hands of minority, proportionality principle in entering and holding public positions, and autonomy of all segments (Lijphart, 1992: 32).

32 There are a lot of other conceptualizations. Dahl has, for example, invented the concept of polyarchy, meaning a political system which is at the same time liberal and participative (Dahl, 1998). Almond and Verba have considered the balance between efficient power to rule and accountability to citizens as one of the most important pillars of democracy. Such a balance can be best kept in conditions of the civic culture (Almond and Verba, 2000: 351, and subsequent). Etc. 
Inter-ethnic and other structural splits and cleavages ${ }^{33}$ generate conflicts and ask for their political formulation and representation into the formal political system. In a way, the presence of different political parties and independent lists can be seen as a method for the relaxation of social tensions. Of course, the very institution and the whole system of local self-government has many advantages in this regard. Inter alia, it prevents political power concentration, localises political conflicts, relaxes interethnic tensions, educates citizens and contributes to democratic political culture, educates politicians for political positions at national level, etc. (Koprić, 2006a: 254-255). This is one of the main reasons why »the introduction of new institutions of local democracy was an inherent and important part of the comprehensive reforms of the early 1990s in EastCentral Europe« (Baldersheim, 2003: 241).

Thus, a composite theoretical circle or model for deepening the understanding of independent local lists phenomenon, consisting of four theories - system theory, transition theory, neo-institutional theory, and democratisation theory - has been outlined.

All possible ways of thinking, attempts to operationalise this composite theory, all the hypotheses, could not be followed in this article. Nevertheless, the issue of local lists independence should be explored once again at this point, within the frame determined by several questions derived from the composite theory. These are the following:

- Is the presence of independent local lists a component of political democratisation or de-democratisation?

- Can they stabilise and consolidate multi-party systems of transitional countries or they promote political fragmentation and destabilisation?

- Do they represent a modern political institution or a sign of political system decline?

On the one hand, by opening possibility to certain small groups of citizens to enter into local electoral competition relatively easy and by widening citizens' election choices, independent local lists are close to the instruments of direct democracy. They are a way of growing direct democracy into representative democracy. However, direct democracy also has

33 Zakošek considers three main cleavages in Croatian transition society which have influenced voters' behaviour: territorial-cultural, ideological-cultural, and socioeconomic cleavages (Zakošek, 2001: 108-110). Šiber has researched two main cleavages in Croatia, historical (two sides during the Second World War) and national (Šiber, 1998). 
well-elaborated shortcomings, where the possibility of manipulation is the most important one. ${ }^{34}$ On the other hand, representation is nowadays seen as part of democracy or even as a better instrument of democracy than forms of direct democracy (Offerdal, 2003: 274-276).

The practice of independent members of local councils in Croatia shows good and bad democratisation potential of independent lists. In many local units they promote the interests of some groups of citizens in a legitimate manner. They are really able to introduce more personal political engagement and familiarity of municipal politicians with their electorate. These are the reasons why assessments according to which their role is quite and generally negative (Kasapović, 2004: 93) cannot be accepted, despite the experienced shortcomings.

It should be admitted that the disadvantages of such lists are obvious in many cases in recent Croatian practice. They may be captured by and bring forward certain very specific vested interests in the local representative bodies, such as the interests of certain businesses, societal groups (e.g., elderly people, a sports club members) or even the interests of a rich entrepreneur or a popular person. Such and similar forms of clientelism should not be treated as desirable. They can also promote only the private interests of the members elected from independent lists, showing »worrying political inconsistency« (Kasapović, 2004: 89). Certain lists enter into coalitions after real blackmailing. The possibility of forming independent lists with intention to facilitate the abuse of financial donations cannot be excluded, which was one of the reasons for passing the new Law on Financing of Political Parties, Independent Lists and Candidates of 2007. Some of the lists were obviously hidden or reserve lists of certain political parties, entering into coalition with the »mother-party« immediately after elections. That shows a kind of cheating political behaviour. One of the motives for forming independent list can be quite lucrative, as every party and independent member of a representative body have the right to finances for regular activities..$^{35}$ Etc.

34 About the shortcomings of referendum see, for example, Cerar, 2001.

35 There is a well-known case of changing status from party members to independent members in the Croatian Parliament during the mandate 2003-2007, mainly because of the rather high amount of money for regular activities. The initiative came from the leading party that has a weak majority. It is considered to be a mode of political corruption whose purpose to weaken the political opposition and stabilise the Government. The same could be possible at local and regional levels, too. 
All the mentioned forms of non-democratic behaviour are at least an indicator of less consolidated and less stable political and party systems in a transition country such as Croatia. An interesting phenomenon or tendency can be noted: some independent lists are trying to transform themselves into the (new) political parties. Along with the described case of independent lists led by Branimir Glavaš and his colleagues, there are others. First of all, independent list led by Tatjana Holjevac in Zagreb has managed to transform itself into the leader of the new political party named Sjedinjene nezavisne liste (United Independent Lists), although the number of lists that joined the new party was quite small. The second attempt might happen in Splitsko-dalmatinska County. Independent local list led by Željko Jerkov from Split succeeded in gathering 27 leaders of the local lists from the municipalities on the territory of Splitsko-dalmatinska County during February 2007 for information sharing purpose, although the media speculated that the real reason was stronger networking or forming a united independent list for the parliamentary elections of 2007. Such a tendency illustrates a kind of distrust in the very institution of independent list by their founders.

Nevertheless, there are cases in which previously dissatisfied party members split from the mother party and form an independent list (or a new political party) very often just for local elections, because in such elections they have at least minimal chances to gain (a small number of) seats and survive politically. Be that what it may, the number of political parties is constantly rising (see also Cular, 2001: 125-130), as well as the number of independent lists competing in local elections. ${ }^{36}$ The tendency of fragmentation of party and political systems is noticeable, although only a few large political parties play real and main roles at the national level.

Fragmentation is to a certain degree connected with instability in a political system. Such instability might be caused by the voters and their changing choices. This phenomenon is probably based on a very low level of social trust, which is even lower than in other post-socialist countries (Šalaj, 2006), as well as on the fact that political profiles of a significant number of parties are not very clear. Additionally, there is strong empirical evidence for a simple dichotomy of ideological cleavages in Croatian society. The first group consists of the proponents of national, religious and traditional values, and the second of the proponents of secular and

36 Independent local lists competed in the $55,8 \%$ of all local self-government units during local elections of 2001 , while the share of such units rose up to $62,1 \%$ in the local elections of 2005. 
modern values. This is a less complex picture than in other countries, both developed and transitional (Zakošek, 1998: 48). Such a simple (too simple) situation has been influencing many political parties, except few largest ones, because they are forced to shift their ground in search of potential electoral base - this is probably the reason why many of them have not got a clear political profile yet.

A moderate approach should be chosen in answering the question about the strengths and weaknesses, functions, nature and final evaluation of independent local lists. Those lists seem to be a very useful political instrument in several ways.

1. Firstly, they are realistic means of contribution to personalisation of local politics, which is a desirable aim from democratisation point of view. Thus, the presence and success of the independent lists can indicate the degree of democracy in the political system development.

2. Despite the possibilities of manipulation, they promote personal accountability to voters. If they are successful, which is more probable in smaller local units, their leaders and other members cannot avoid social pressure and cannot evade the dense network of more personalised social relationships. In the long run, this pressure has to result in firmer accountability mechanisms, at least in smaller units.

3. Similar to the situation with the instruments of direct democracy, the very presence of possibility to use them may relax tensions in political and societal life. Independent lists can be used whenever there are some cleavages at the micro level where large national political parties cannot respond, at least not in a short time. Their success should not be treated as a negative phenomenon, because it only indicates that voters have need to express their political will through them, not through other, probably more important political actors, such as political parties and/or directly elected mayors.

4. Usage in multinational local communities is one of the special cases of previous argument, but should be mentioned separately because of the particular importance interethnic relations have in contemporary building of democratic institutions.

5. Independent local lists are in a way substituting political parties in smaller units, because smaller units are not, as a rule, in the focus of political parties, at least they are not in the limelight of large 
national parties. The penetration of political parties in smaller units is not so deep because of the economic principle "probable costs outgrow possible results«. In such a way, independent local lists can be seen as additional but useful means of political system stabilisation.

6. Independent local lists can motivate some voters to vote by filling possible gaps in political offer and in such a way increase democratic legitimacy of the whole political system.

7. Independent local lists can be and should be, in principle, only additional instrument of democracy. Croatian data about successful lists show that there was approximately one third of unsuccessful independent lists; approximately one third were successful but managed to gain only up to $10 \%$ of the total number of seats in their respective units, about one sixth gained more than $10 \%$ and up to $20 \%$ of the total number of seats, etc. (Appendix 6 ).

The realisation of the described advantages depends on realistic circumstances. Some of the circumstances can be dealt with intentionally in a short time, such as certain pieces of legal regulation. Some of them can be dealt with, but this is not probable, such as the territorial organisation of the country. Some of them can be developed, but in the long run, such as democratic or civic culture. Some of them cannot be treated intentionally, such as importance and influence of ideological cleavages. Etc.

The success of independent local list depends on many different factors. Some of them can be mentioned for the illustration purposes. If a legal system provided for various, appropriate and well-designed channels of direct democracy, there should be narrower space and less need for independent lists. If civil society is weak, there should be greater need for independent lists; however, it might be questionable whether they will be generated and accepted by citizens. If there is a stable party system in a country, there should be less need for independent local lists, but under one more condition: other components of a political system should function well. If there are many social, ideological and other cleavages, there is wider space and greater need for a wide variety of different political actors that could represent the interests of all social segments in a formal political system. Numerous other hypotheses can be developed and researched.

The final assessment of the role of independent lists has to take into account all these and some additional circumstances and contingencies. It has to take into account the composite indicators of their value and 
should not be one-sided. Surely, they should not be blamed for all sorts of undesirable political behaviour, such as entering into fuzzy coalitions. If there were no independent lists, certain political parties would probably be in position to tip the balance. However, at the end it should be noted that the connotation of the word »independent《 is in collision with the real role of independent lists. They are not really independent. If so, they would be value and interest-free. On the contrary, their role, similar to the role of political parties, is to be interest representative acting on behalf of a social segment or a community of citizens.

\section{Conclusion}

Independent local lists should be treated in broader context outlined by a composite theoretical mixture. In such a way, analyses and research can be richer, more productive, more appropriate and more useful. A productive theoretical frame might be composed of the system theory, transition theory, neo-institutional theory, and democratisation theory. Such a theoretical frame might seem to be too wide, too general, and designed for a broader and wider, more complex phenomenon. However, a more general theoretical frame can be more productive, too. It can be capable of catching not only the issues closely connected with independent lists, but also the issues connected with all dimensions of the broader relevant context. This context includes local self-government system and developmental processes in local governance, party and political system, legal regulation, and real life of institutions in the public sphere, wider social environment, etc.

Nevertheless, one of the purposes of this article is to stimulate discussion about a broader theoretical frame, not to design it, at least not in too many details. I tried to come to some basic theoretical ideas by reviewing a concrete situation with independent local lists in the Croatian general local election of 2005. In due course, after the consolidation of theoretical frame, subsequent empirical research seems to be quite necessary. Reviewing the statistical data and storytelling may give very valuable qualitative insights, but cannot substitute additional quantitative empirical research. 


\section{References}

Almond, Gabriel A., Sidney Verba (2000) Civilna kultura (original: The Civic Culture: Political Attitudes and Democracy in Five Nations, 1963). Zagreb: Politička kultura.

Antic, Teodor (2002) Decentralization of Public Administration in the Republic of Croatia. In: Gábor Péteri (ed.) Mastering Decentralization and Public Administration Reforms in Central and Eastern Europe. Budapest: LGI - Open Society Institute, pp. 121-135.

Augustinovic-Pavičic, Greta (2002) Structure and Relationship of Legislative and Executive Powers in the Units of Local and Regional Self-Government in Croatia. In: Executive and Legislature at Local Level. Zagreb: Friedrich Ebert Stiftung, pp. 99-112.

Antulov, Dragan (2000) Regionalism in Croatia: Between Tradition and Reality. Central Europe Review 2(19): 1-9.

Baldersheirn, Harald (2003) Towards Normalisation of Local Democracy in East-Central Europe. A Developmental Approach to Institutional Reform. In: Harald Baldersheirn, Michal Illner, Hellmut Wollmann (eds.) Local Democracy in Post-Communist Europe. Opladen: Leske + Budrich, pp. 241-261.

Bíró, Anna-Mária, Petra Kovács (eds.) (2001) Diversity in Action: Local Public Management of Multi-Etbnic Communities in Central and Eastern Europe. Budapest: LGI - Open Society Institute

Cerar, Miro (2001) Razmerje med neposredno in posredno demokracijo v slovenski ustavni ureditvi (The Relationship between Direct and Indirect Democracy in Slovenia's Constitutional System). Jama uprava, vol. 37, no. 2, pp. 133-163.

Čepulo, Dalibor (2000) Položaj i ustroj hrvatskih gradova prema Zakonu o uređenju gradskih općina iz 1881. godine (Status and Organisation of Croatian Towns Under the Law on Regulation of the Towns' Self-Government of 1881). Hrvatska javna uprava, vol. 2, no. 1, pp. 83-120.

Cular, Goran (2001) Vrste stranačke kompeticije i razvoj stranačkog sustava. In: Mirjana Kasapović (ed.) Hrvatska politika 1990.-2000. (Croatian Politics 1990-2000). Zagreb: Fakultet političkih znanosti Sveučilišta u Zagrebu, pp. $123-146$.

Čular, Goran, Nebojša Blanuša (2001) Rezultati parlamentamih i predsjedničkih izbora i referenduma u Hrvatskoj 1990.-2000. (Parliamentary and Presidential Elections Results and Results of Referenda in Croatia 1990-2000). In: Mirjana Kasapovic (ed.) Hrvatska politika 1990,-2000. (Croatian Politics 1990-2000). Zagreb: Fakultet političkih znanosti Sveučilišta u Zagrebu, pp. 223-236.

Dahl, Robert A. (1998) Poliarbija; participacija i opozicija (original: Polyarcby: Participation and Opposition, 1971). Zagreb: Politička kultura.

Eurić, Ivana (2004) A Success Story: Local Governance in the Multiethnic Municipality of Kneževi Vinogradi, Croatia. In: Nenad Dimitrijević and Petra 
Kovács (eds.) Managing Hatred and Distrust: The Prognosis for Post-Conflict Settlement in Multiethnic Communities in the Former Yugoslavia. Budapest: LGI - Open Society Institute, pp. 83-98.

Gál, Kinga (ed.) (2002) Minority Governance in Europe. Budapest: LGI - Open Society Institute

Gosselin, Tania (2004) Info-Klub: Creating a Common Public Sphere for Citizens of Vukovar. In: Nenad Dimitrijević and Petra Kovács (eds.) Managing Hatred and Distrust: The Prognosis for Post-Conflict Settlement in Multietbnic Communities in the Fomer Yugoslavia. Budapest: LGI - Open Society Institute, pp. 65-79.

Grdešić, Ivan, Mirjana Kasapović, Ivan Šiber, Nenad Zakošek (1991) Hrvatska u izborima'90. (Croatia in Elections of '90). Zagreb: Naprijed

Hrženjak, Juraj (2004) Lokalna i regionalna samouprava u Republici Hrvatskoj (Local and Regional Self-Government in the Republic of Croatia). Zagreb: Informator

Ivanišević, Stjepan (2006) Funkcioniranje Gradske skupštine Zagreba 2001-2006. (Functioning of the City of Zagreb Assembly 2001-2006). Unpublished research report

Ivaniševic, Stjepan, Ivan Kopric, Jasna Omejec, Jure Šimoviદ (2001) Local Govemment in Croatia. In: Emilia Kandeva (ed.) Stabilization of Local Govermments. Budapest: LGI - Open Society Institute, pp. 179-240.

Jelušić, Mario (2007) Novine u Zakonu o financiranju političkih stranaka, nezavisnih lista $i$ kandidata (Novelties in the Law on Financing of Political Parties, Independent Lists and Candidates). Informator, vol. 55, no. 5518, pp. 1-2.

Kasapović, Mirjana (2004) Lokalno izborno pravo u Hrvatskoj u komparativnoj perspektivi (The Law on Local Elections in Croatia in Comparative Perspective). In: Zdravko Petak, Mirjana Kasapović, Dražen Lalić, Lokalna politika u Hrvatskoj-tri studije (Local Politics in Croatia - Tbree Studies). Zagreb: Fakultet političkih znanosti Sveučilišta u Zagrebu

Kopric, Ivan (2003) Local Govemment Development in Croatia. Problems and Value Mix. In: Harald Baldersheim, Michal Illner, Hellmut Wollmann (eds.) Local Democracy in Post-Communist Europe. Opladen: Leske + Budrich, pp. $181-210$.

Koprić, Ivan (ed.) (2003a) Legislative Frameworks for Decentralisation in Croatia. Zagreb: Faculty of Law and Croatian Law Centre

Koprić, Ivan (2006) O neposrednom izboru gradonačelnika i općinskog načelnika (On Direct Elections of Town and Commune Mayors). Informator, vol. 53, no. 5399 , p. 9.

Koprić, Ivan (2006) Različite koncepcije o ulozi lokalnih jedinica (Different Concepts on the Role of Local Units). In: Jama uprava (Public Administration). Zagreb: Društveno veleučilište u Zagrebu i Pravni fakultet Sveučilišta u Zagrebu

Koprić, Ivan (2007) Regionalism and Regional Development Policy in Croatia. In: Ilona Pálné Kovács (ed.) Political Studies of Pécs IV - Regional Decentralisation in Central and Eastem Europe. Pécs: University of Pécs, pp. 87-110. 
Koprić, Ivan (2007) Upravljanje decentralizacijom kao novi pristup razvoju sustava lokalne samouprave (Decentralisation Management as a new Approach to the Development of Local Self-Government System). In: Zvonimir Lauc (ed.) Lokalna samouprava i decentralizacija (Local Self-Government and Decentralisation). Osijek: Akademija pravnih znanosti Hrvatske (forthcoming)

Larsen, Helge O. (2002) Directly Elected Mayors: Democratic Renewal or Constitutional Confusion? In: Janice Caulfield and Helge O. Larsen (eds.) Local Government at the Millenium. Opladen: Leske + Budrich

Lewis, Paul G. (2004) Central European Party Systems in the Context of EU Enlargement. In: Attila Ágh (ed.) Post-Accession in East Central Europe: The Emergence of the EU 25. Budapest: Hungarian Centre for Democracy Studies

Lijphart, Arend (1992) Demokracija u pluralnim društvima (original: Democracy in Plural Societies: A Comparative Exploration, 1977). Zagreb: Globus i Skolska knjiga

Lozina, Duško (2004) Lokalna samouprava (Local Self-Govemment). Split: Pravni fakultet Sveučilišta u Splitu

March, James G., Johan P. Olsen (1995) Democratic Governance. New York etc.: The Free Press

Marčetiદ, Gordana (2005) Jawni shužbenici i tranzicija (Public Servants and Transition). Zagreb: Društveno veleučilište u Zagrebu and Kondrad Adenauer Stiftung

Marčetič, Gordana (2006) Upravljanje ljudskim potencijalima u janoj upravi (Human Potentials Management in Public Administration) (Unpublished doctoral thesis). Zagreb: Pravni fakultet Sveučilišta u Zagrebu

Mingers, John (1995) Self-Producing Systems: Implications and Applications of Autopoiesis. New York and London: Plenum Press

Offerdal, Audun (2003) Whose Mayor? Representational Roles in Local Politics. In: Harald Baldersheim, Michal Illner, Hellmut Wollmann (eds.) Local Democracy in Post-Communist Europe. Opladen: Leske + Budrich, pp. 181-210.

Omejec, Jasna (2002) Izborni sustav i rezultati lokalnih izbora održanih 20. svibnja 2001. (The Electoral System and the Results of the Local Elections Held on 20 May 2001). Hrvatska jama uprava 4(1): 115-156

Pavic, Željko (2006) Veličina lokalnih jedinica (Size of Local Units). In: Group of authors, Jama uprava (Public Administration). Zagreb: Društveno veleučilište u Zagrebu i Pravni fakultet Sveučilišta u Zagrebu

Perko-Šeparović, Inge, Juraj Hrženjak (1982) Organizacija teritorija i samoupravlianje (Organisation of the Territory and Self-Management). Zagreb: Informator

Petak, Zdravko (2006) Policy in a Transitional Context: Performing Decentralisation in Croatia. In: H. K. Colebatch (ed.) The Work of Policy. Lanham etc.: Lexington Books, pp. 83-106.

Podolnjak, Robert (2005) Neposredan izbor (grado)nacelnika: europska iskustva $i$ brvatski izazov (Direct Elections of Town and Commune Mayors: European Experiences and Croatian Cballenge). Varaždin

Pusić, Eugen (1989) Društvena regulacija (Social Regulation). Zagreb: Globus i Pravni fakultet Sveučilišta u Zagrebu 
Putnam, Robert D. (1993) Making Democracy Work: Civic Traditions in Modern Italy. Princeton: Princeton University Press

Schöpflin, George (2001) Minorities and Democracy. In: Anna-Mária Bíró and Petra Kovács (eds.) Diversity in Action: Local Public Management of Multi-Etbnic Communities in Central and Eastern Europe. Budapest: LGI - Open Society Institute, pp. 5-18.

Sokol, Smiljko (2006) O izborima za Hrvatski sabor i lokalna predstavnička tijela i njihove moguće promjene te promjene izbora načelnika, gradonačelnika i župana (About Elections for Croatian Parliament and for Local Representative Bodies, Their Possible Changes, and Changes in the Elections of Mayors, Town Mayors and County Govemors). Informator, vol. 54, no. 5409, pp. 1-3.

Šalaj, Berto (2006) Socijalno povjerenje: Hrvatska 1995-2003. (Social Trust: Croatia 1995-2003). Anali Hrvatskog politološkog društva 2005, vol. 2, pp. $35-56$.

Siber, Ivan (1998) Povijesni i etnički rascjepi u hrvatskom društvu (Historical and Ethnical Cleavages in Croatian Society). In: Mirjana Kasapović, Ivan Siber, Nenad Zakošek, Birači i demokracija (Voters and Democracy). Zagreb: Alinea.

Vujčic, Vladimir (2006) Razumijevanje demokracije kod mladih u Hrvatskoj (Understanding of Democracy among Young People in Croatia). Anali Hrvatskog politološkog društva 2005, vol. 2, pp. 57-80.

Wollmann, Hellmut (2000) Local Govemment Modemization in Germany: Between Incrementalism and Reform Waves. Public Administration, vol. 78, no. 4, pp. 915-936.

Wollmann, Hellmut (2001) Public Sector Reforms and Evaluation: Trajectories and Trends. An Intemational Overview. Revista Internacional de Estudos Politicos, vol. 3, especial, pp. 11-37.

Zakošek, Nenad (1998) Ideološki rascjepi i stranačke preferencije hrvatskih birača (Ideological Cleavages and Party Preferences of Croatian Voters). In: Mirjana Kasapović, Ivan Šiber, Nenad Zakošek, Birači i demokracija (Voters and Democracy). Zagreb: Alinea

Zakošek, Nenad (2001) Struktura biračkog tijela i političke promjene u siječanjskim izborima 2000. (The Structure of Electoral Body and Political Changes in Elections of January 2000). In: Mirjana Kasapović (ed.) Hrvatska politika 1990.-2000. (Croatian Politics 1990-2000). Zagreb: Fakultet političkih znanosti Sveučilišta u Zagrebu, pp. 99-122.

\section{Legal sources}

The Constitution of the Republic of Croatia, Narodne novine (Official Gazette of the Republic of Croatia; NN) no. 41/2001 - consolidated text

Constitutional Law on the Rights of National Minorities, NN no. 155/2002.

Law on the Elections of Members of the Representative Bodies of Local and Regional Self-Government Units, NN no. 44/2005. 
Law on the Financing of Political Parties, Independent Lists and Candidates, NN no. $1 / 2007$.

Law on Local and Regional Self-Government, NN no. 33/2001, 60/2001, $129 / 2005$.

Law on Referendum and Other Forms of Personal Participation of Citizens in the State Authority and Local and Regional Self-Government, NN no. 33/1996, 92/2001, 44/2006, 58/2006.

Law on Territories of the Counties, Towns and Communes in the Republic of Croatia, NN no. 86/2006.

Law on Youth Councils, NN no. 23/2007.

\section{Appendixes}

\section{Basic indicators of Croatian counties (situation on 31 December 2006)}

\begin{tabular}{|c|c|c|c|c|c|c|}
\hline County & $\begin{array}{c}\text { Territory } \\
\mathrm{km}^{2}\end{array}$ & $\begin{array}{l}\text { Number } \\
\text { of } \\
\text { inhabitants }\end{array}$ & $\begin{array}{c}\text { Inhabitants } / \\
/ \mathrm{km}^{2}\end{array}$ & $\begin{array}{c}\text { Number } \\
\text { of } \\
\text { cities }\end{array}$ & $\begin{array}{l}\text { Number } \\
\text { of } \\
\text { communes }\end{array}$ & $\begin{array}{l}\text { Number } \\
\text { of } \\
\text { settlements }\end{array}$ \\
\hline Zagrebačka & 3.060 & 309.696 & 101,2 & 9 & 25 & 697 \\
\hline $\begin{array}{l}\text { Krapinsko- } \\
\text {-zagorska }\end{array}$ & 1.229 & 142.432 & 115,9 & 7 & 25 & 423 \\
\hline $\begin{array}{l}\text { Sisačko- } \\
\text {-moslavačka }\end{array}$ & 4.468 & 185.387 & 41,5 & 6 & 13 & 456 \\
\hline Karlovačka & 3.626 & 141.787 & 39,1 & 5 & 17 & 649 \\
\hline Varaždinska & 1.262 & 184.769 & 146,4 & 6 & 22 & 301 \\
\hline $\begin{array}{l}\text { Koprivničko- } \\
\text {-križevačka }\end{array}$ & 1.748 & 124.467 & 71,2 & 3 & 22 & 264 \\
\hline $\begin{array}{l}\text { Bjelovarsko- } \\
\text {-bilogorska }\end{array}$ & 2.640 & 133.084 & 50,4 & 5 & 18 & 323 \\
\hline $\begin{array}{l}\text { Primorsko- } \\
\text {-goranska }\end{array}$ & 3.588 & 305.505 & 85,1 & 14 & 22 & 510 \\
\hline $\begin{array}{l}\text { Ličko- } \\
\text {-senjska }\end{array}$ & 5.353 & 53.677 & 10,0 & 4 & 8 & 252 \\
\hline $\begin{array}{l}\text { Virovitičko- } \\
\text {-podravska }\end{array}$ & 2.024 & 93.389 & 46,1 & 3 & 13 & 190 \\
\hline $\begin{array}{l}\text { Požeško- } \\
\text {-slavonska }\end{array}$ & 1.823 & 85.831 & 47,1 & 5 & 5 & 277 \\
\hline $\begin{array}{l}\text { Brodsko- } \\
\text {-posavska }\end{array}$ & 2.030 & 176.765 & 87,1 & 2 & 26 & 185 \\
\hline Zadarska & 3.646 & 162.045 & 44,4 & 6 & 28 & 226 \\
\hline
\end{tabular}


Ivan Kopric: Independent Local Lists in Croatia ...

\begin{tabular}{|l|r|r|r|r|r|c|}
\hline $\begin{array}{l}\text { Osječko- } \\
\text {-baranjska }\end{array}$ & 4.155 & 330.506 & 79,5 & 7 & 35 & 263 \\
\hline $\begin{array}{l}\text { Šibensko- } \\
\text {-kninska }\end{array}$ & 2.984 & 112.891 & 37,8 & 5 & 15 & 196 \\
\hline $\begin{array}{l}\text { Vukovarsko- } \\
\text {-srijemska }\end{array}$ & 2.454 & 204.768 & 83,4 & 5 & 26 & 85 \\
\hline $\begin{array}{l}\text { Splitsko- } \\
\text {-dalmatinska }\end{array}$ & 4.540 & 463.676 & 102,1 & 16 & 39 & 367 \\
\hline Istarska & 2.813 & 206.344 & 73,4 & 10 & 31 & 656 \\
\hline $\begin{array}{l}\text { Dubrovačko- } \\
\text {-neretvanska }\end{array}$ & 1.781 & 122.870 & 69,0 & 5 & 17 & 231 \\
\hline Medimurska & 729 & 118.426 & 162,4 & 3 & 22 & 129 \\
\hline $\begin{array}{l}\text { City of } \\
\text { Zagreb }\end{array}$ & 641 & 779.145 & $1.215,5$ & 1 & 0 & 70 \\
\hline CROATIA & 56.594 & 4.437 .460 & 78,4 & $126+1$ & 429 & 6.750 \\
\hline
\end{tabular}

\section{The large towns}

\begin{tabular}{|c|c|c|c|}
\hline Town & Number of inhabitants & Town & Number of inhabitants \\
\hline Split & 188.694 & Sisak & 52.236 \\
\hline Rijeka & 144.043 & Šibenik & 49.373 \\
\hline Osijek & 114.616 & Varaždin & 49.075 \\
\hline Zadar & 72.718 & Dubrovnik & 43.770 \\
\hline Velika Gorica & 63.517 & Bjelovar & 41.869 \\
\hline Slavonski Brod & 60.946 & Samobor & 36.206 \\
\hline Karlovac & 59.395 & Vinkovci & 35.912 \\
\hline Pula & 58.594 & & \\
\hline
\end{tabular}

\section{Independent local lists (ILLs) in 2005 general local elections}

\begin{tabular}{|c|c|c|c|c|c|c|}
\hline \multirow{7}{*}{ County } & $\begin{array}{c}\text { Number } \\
\text { of } \\
\text { LSGUs } \\
\text { with and } \\
\text { without } \\
\text { ILLs in } \\
\text { elections }\end{array}$ & $\begin{array}{c}\text { Number } \\
\text { of } \\
\text { ILLs } \\
\text { in } \\
\text { elections }\end{array}$ & $\begin{array}{c}\text { Number } \\
\text { of } \\
\text { ILLs } \\
\text { which } \\
\text { gain } \\
\text { seats }\end{array}$ & $\begin{array}{c}\text { Number } \\
\text { of } \\
\text { seats } \\
\text { gained } \\
\text { by } \\
\text { ILLs }\end{array}$ & $\begin{array}{c}\text { Total } \\
\text { number } \\
\text { of seats in } \\
\text { LSGUs in } \\
\text { which } \\
\text { ILLs } \\
\text { participated } \\
\text { in elections }\end{array}$ & $\begin{array}{c}\text { ILLs } \\
\text { seats } \\
\text { share } \\
(5: 6) \\
\%\end{array}$ \\
\hline Zagrebačka & 2 & 3 & 4 & 5 & 6 & 7 \\
\hline Towns & $6 / 2$ & 12 & 5 & 11 & 124 & 8,9 \\
\hline Communes & $12 / 14$ & 22 & 18 & 38 & 162 & 23,5 \\
\hline
\end{tabular}




\begin{tabular}{|c|c|c|c|c|c|c|}
\hline $\begin{array}{l}\text { Krapinsko- } \\
\text {-zagorska }\end{array}$ & & 2 & - & - & 41 & 0 \\
\hline Towns & $5 / 2$ & 11 & 7 & 11 & 79 & 13,9 \\
\hline Communes & $16 / 9$ & 21 & 12 & 22 & 208 & 10,6 \\
\hline $\begin{array}{l}\text { Sisačko- } \\
\text {-moslavačka }\end{array}$ & & 1 & - & - & 49 & 0 \\
\hline Towns & $6 /-$ & 12 & 3 & 4 & 122 & 3,3 \\
\hline Communes & $9 / 4$ & 16 & 12 & 21 & 134 & 15,7 \\
\hline Karlovačka & & - & - & - & & - \\
\hline Towns & $4 / 1$ & 7 & 3 & 5 & 72 & 6,9 \\
\hline Communes & $10 / 7$ & 11 & 10 & 17 & 116 & 14,7 \\
\hline Varaždinska & & - & - & - & & - \\
\hline Towns & $2 / 4$ & 2 & 1 & 1 & 30 & 3,3 \\
\hline Communes & $3 / 19$ & 4 & 3 & 3 & 41 & 7,3 \\
\hline $\begin{array}{l}\text { Koprivničko- } \\
\text {-križevačka }\end{array}$ & & - & - & - & & - \\
\hline Towns & $2 / 1$ & 2 & - & - & 44 & 0 \\
\hline Communes & $11 / 11$ & 13 & 12 & 27 & 139 & 19,4 \\
\hline $\begin{array}{l}\text { Bjelovarsko- } \\
\text {-bilogorska }\end{array}$ & & 1 & - & - & 41 & 0 \\
\hline Towns & $2 / 3$ & 3 & 1 & 1 & 34 & 2,9 \\
\hline Communes & $3 / 15$ & 3 & 2 & 3 & 43 & 7,0 \\
\hline $\begin{array}{l}\text { Primorsko- } \\
\text {-goranska }\end{array}$ & & 1 & - & - & 41 & 0 \\
\hline Towns & $10 / 4$ & 19 & 11 & 25 & 170 & 14,7 \\
\hline Communes & $16 / 5$ & 28 & 21 & 41 & 194 & 21,1 \\
\hline Ličko-senjska & & - & - & - & & - \\
\hline Towns & $2 / 2$ & 3 & 1 & 4 & 28 & 14,3 \\
\hline Communes & $4 / 4$ & 7 & 5 & 10 & 52 & 19,2 \\
\hline $\begin{array}{l}\text { Virovitičko- } \\
\text {-podravska }\end{array}$ & & - & - & - & & - \\
\hline Towns & $2 / 1$ & 3 & 1 & 1 & 38 & 2,6 \\
\hline Communes & $6 / 7$ & 8 & 6 & 11 & 82 & 13,4 \\
\hline $\begin{array}{l}\text { Požeško- } \\
\text {-slavonska } \\
\end{array}$ & & 1 & - & - & 42 & 0 \\
\hline Towns & $3 / 1$ & 4 & 2 & 2 & 47 & 4,3 \\
\hline Communes & $2 / 4$ & 4 & - & - & 28 & 0 \\
\hline $\begin{array}{l}\text { Brodsko- } \\
\text {-posavska }\end{array}$ & & 1 & - & - & 51 & 0 \\
\hline Towns & $2 /-$ & 5 & 2 & 5 & 44 & 11,4 \\
\hline Communes & $10 / 16$ & 11 & 9 & 14 & 130 & 10,8 \\
\hline Zadarska & & 1 & 1 & 3 & 41 & 7,3 \\
\hline Towns & $5 / 1$ & 15 & 9 & 16 & 85 & 18,8 \\
\hline
\end{tabular}


Ivan Kopric: Independent Local Lists in Croatia ...

\begin{tabular}{|c|c|c|c|c|c|c|}
\hline Communes & $23 / 4$ & 34 & 26 & 39 & 297 & 13,1 \\
\hline $\begin{array}{l}\text { Osječko- } \\
\text {-baranjska }\end{array}$ & & 1 & 1 & 14 & 47 & 29,8 \\
\hline Towns & $7 /-$ & 21 & 7 & 23 & 135 & 17,0 \\
\hline Communes & $25 / 10$ & 49 & 39 & 113 & 318 & 35,5 \\
\hline $\begin{array}{l}\text { Šibensko- } \\
\text {-kninska }\end{array}$ & & - & - & - & & - \\
\hline Towns & $3 / 2$ & 5 & 1 & 8 & 57 & 14,0 \\
\hline Communes & $9 / 5$ & 16 & 13 & 28 & 103 & 27,2 \\
\hline $\begin{array}{l}\text { Vukovarsko- } \\
\text {-srijemska }\end{array}$ & & 2 & - & - & & 0 \\
\hline Towns & $2 / 2$ & 4 & - & - & 42 & 0 \\
\hline Communes & $14 / 12$ & 28 & 22 & 42 & 178 & 23,6 \\
\hline $\begin{array}{l}\text { Splitsko- } \\
\text {-dalmatinska }\end{array}$ & & 2 & - & - & 51 & 0 \\
\hline Towns & $14 / 2$ & 26 & 16 & 27 & 224 & 12,1 \\
\hline Communes & $29 / 10$ & 55 & 38 & 70 & 336 & 20,8 \\
\hline Istarska & & 1 & - & - & 41 & 0 \\
\hline Towns & $9 / 1$ & 23 & 13 & 25 & 153 & 16,3 \\
\hline Communes & $22 / 7$ & 31 & 29 & 83 & 268 & 31,0 \\
\hline $\begin{array}{l}\text { Dubrovačko- } \\
\text {-neretvanska }\end{array}$ & & 1 & 1 & 7 & 41 & 17,1 \\
\hline Towns & $5 /-$ & 8 & 6 & 21 & 83 & 25,3 \\
\hline Communes & $8 / 9$ & 14 & 12 & 14 & 91 & 15,4 \\
\hline Medimurska & & - & - & - & & - \\
\hline Towns & $3 /-$ & 5 & 4 & 5 & 53 & 9,4 \\
\hline Communes & $14 / 8$ & 22 & 17 & 33 & 186 & 17,7 \\
\hline Zagreb & & 4 & 2 & 7 & 51 & 13,7 \\
\hline $\begin{array}{l}\text { Towns - total } \\
(\Sigma)+\text { Zagreb } \\
\%\end{array}$ & $\begin{array}{c}95 / 29 \\
76,6 / \\
23,4\end{array}$ & 194 & 95 & 202 & 1.715 & 11,8 \\
\hline $\begin{array}{l}\text { Communes } \\
-\Sigma \%\end{array}$ & $\begin{array}{c}246 / 180 \\
57,7 / \\
42,3\end{array}$ & 397 & 306 & 629 & 3.106 & 20,3 \\
\hline $\begin{array}{l}\text { Counties }-\Sigma \\
\%\end{array}$ & $\begin{array}{c}13 / 7 \\
65 / 35\end{array}$ & 17 & 2 & 21 & 88 & 23,9 \\
\hline $\begin{array}{c}\text { CROATLA } \\
\text { - TOTAL } \\
\%\end{array}$ & $\begin{array}{c}354 / \\
216 \\
62,1 / \\
37,9\end{array}$ & 608 & 403 & 852 & 4.909 & 17,4 \\
\hline
\end{tabular}




\section{Additional information on ILLs success in 2005 general local elections}

\begin{tabular}{|l|c|cc|cc|c|c|}
\hline $\begin{array}{l}\text { Self- } \\
\text {-government } \\
\text { units }\end{array}$ & Total ILLs & $\begin{array}{c}\text { Successful } \\
\text { ILLs } \\
\%\end{array}$ & $\begin{array}{c}\text { Unsuccessful } \\
\text { ILLs } \\
\%\end{array}$ & $\begin{array}{c}\text { Gained } \\
\text { seats }\end{array}$ & $\begin{array}{c}\text { Average } \\
(5: 3)\end{array}$ \\
\hline \multicolumn{1}{|c|}{1} & 2 & \multicolumn{2}{|c|}{3} & \multicolumn{2}{|c|}{4} & 5 & 6 \\
\hline Communes & 397 & 306 & 77,1 & 91 & 22,9 & 629 & 2,1 \\
\hline Towns & 194 & 95 & 49,0 & 99 & 51,0 & 202 & 2,1 \\
\hline Counties & 17 & 2 & 11,8 & 15 & 88,2 & 21 & 10,5 \\
\hline CROATIA & $\mathbf{6 0 8}$ & $\mathbf{4 0 3}$ & $\mathbf{6 6 , 3}$ & $\mathbf{2 0 5}$ & $\mathbf{3 3 , 7}$ & $\mathbf{8 5 2}$ & $\mathbf{2 , 1}$ \\
\hline
\end{tabular}

5. The most successful examples - ILLs which won the elections in their respective local self-government units

\begin{tabular}{|l|cc|c|c|}
\hline $\begin{array}{c}\text { Localself-government } \\
\text { unit }\end{array}$ & \multicolumn{2}{|c|}{$\begin{array}{c}\text { No. of seats } \% \\
\text { (from total) }\end{array}$} & No. of votes & $\begin{array}{c}\text { No. of } \\
\text { inhabitants }\end{array}$ \\
\hline Trnava c & $\mathbf{1 0 / 1 3}$ & 76,9 & 635 & $\mathbf{1 . 9 0 0}$ \\
\hline Primošten c & $8 / 11$ & 72,7 & 1.061 & 2.992 \\
\hline Domašinec c & $9 / 13$ & 69,2 & 560 & 2.459 \\
\hline Sveta Nedelja c & $10 / 15$ & 66,7 & 880 & 2.909 \\
\hline Metković t & $11 / 17$ & 64,7 & 3.872 & 15.384 \\
\hline Bale c & $7 / 11$ & 63,6 & 336 & 1.047 \\
\hline Žumberak c & $8 / 13$ & 61,5 & 365 & 1.185 \\
\hline Jagodnjak c & $5 / 9$ & 55,6 & 476 & 2.147 \\
\hline Mošćenička Draga c & $5 / 9$ & 55,6 & 440 & 1.641 \\
\hline Ernestinovo c & $6 / 11$ & 54,5 & 466 & 2.225 \\
\hline Lokvičići c & $6 / 11$ & 54,5 & 271 & 1.037 \\
\hline Viškovci c & $6 / 11$ & 54,5 & 357 & 2.060 \\
\hline Zagorska Sela c & $6 / 11$ & 54,5 & 215 & 1.197 \\
\hline
\end{tabular}

6. Distribution of ILLs according to the percentage of seats

\begin{tabular}{|l|c|c|c|c|c|c|c|c|c|}
\hline $\begin{array}{l}\text { Percentage } \\
\text { of seats }\end{array}$ & $\begin{array}{c}\text { No } \\
\text { seats }\end{array}$ & -10 & $10-20$ & $20-30$ & $30-40$ & $40-50$ & $50-60$ & $60-70$ & $70-80$ \\
\hline No. of lists & 205 & 203 & 108 & 44 & 26 & 9 & 6 & 5 & 2 \\
\hline $\begin{array}{l}\% \\
(608=100)\end{array}$ & 33,7 & 33,4 & 17,8 & 7,2 & 4,3 & 1,5 & 1,0 & 0,8 & 0,3 \\
\hline
\end{tabular}




\section{Success of ILLs in the City of Zagreb territorial elections of 2000 and 2005}

\begin{tabular}{|c|c|c|c|c|c|c|c|c|}
\hline \multirow{2}{*}{$\begin{array}{l}\text { City quarter } \\
\text { Election } \\
\text { year }\end{array}$} & \multirow[t]{2}{*}{$\begin{array}{l}\text { No. of } \\
\text { inhabit. }\end{array}$} & $\begin{array}{l}\text { No. of } \\
\text { seats won } \\
\text { by parties }\end{array}$ & \multicolumn{2}{|c|}{$\begin{array}{l}\text { No. of } \\
\text { seats won } \\
\text { by ILLs }\end{array}$} & \multicolumn{2}{|c|}{$\begin{array}{l}\text { Total no. } \\
\text { of seats }\end{array}$} & \multicolumn{2}{|c|}{$\begin{array}{l}\text { Share of } \\
\text { ILLs' } \\
\text { seats } \\
(4: 5) \%\end{array}$} \\
\hline & & $2000 \quad 2005$ & 200 & 2005 & 2000 & 2005 & $200 \mathrm{C}$ & 2005 \\
\hline 1 & 2 & 3 & & 4 & & 5 & & 6 \\
\hline Donji grad & 45.178 & 19 & - & - & 19 & 15 & - & - \\
\hline $\begin{array}{l}\text { Gornji } \\
\text { grad - } \\
\text { Medveščak }\end{array}$ & 36.475 & 15 & - & - & & 15 & - & - \\
\hline Trnje & 45.199 & 19 & - & 1 & 19 & 15 & - & 6,7 \\
\hline Maksimir & 49.449 & 18 & 1 & - & 19 & 15 & 5,3 & - \\
\hline $\begin{array}{l}\text { Peščenica - } \\
\text { Žitnjak }\end{array}$ & 58.349 & 19 & - & - & 19 & 19 & - & - \\
\hline $\begin{array}{l}\text { Novi Zagreb } \\
\text { - istok }\end{array}$ & 65.424 & 19 & - & 1 & 19 & 19 & - & 5,3 \\
\hline $\begin{array}{l}\text { Novi Zagreb } \\
\text { - zapad }\end{array}$ & 47.163 & 14 & 1 & 1 & 15 & 15 & 6,7 & 6,7 \\
\hline $\begin{array}{l}\text { Trešnjevka } \\
\text { - sjever }\end{array}$ & 55.352 & 19 & - & - & 19 & 19 & - & - \\
\hline $\begin{array}{l}\text { Trešnjevka - } \\
\text { jug }\end{array}$ & 67.050 & 19 & - & - & 19 & 19 & - & - \\
\hline Črnomerec & 38.679 & 15 & - & - & 15 & 15 & - & - \\
\hline $\begin{array}{l}\text { Gornja } \\
\text { Dubrava }\end{array}$ & 61.112 & 19 & - & 1 & 19 & 19 & - & 5,3 \\
\hline $\begin{array}{l}\text { Donja } \\
\text { Dubrava } \\
\end{array}$ & 35.920 & 15 & - & - & 15 & 15 & - & - \\
\hline Stenjevec & 40.949 & 12 & 3 & 1 & 15 & 15 & 20 & 6,7 \\
\hline $\begin{array}{l}\text { Podsused } \\
\text { - Vrapče }\end{array}$ & 42.341 & 15 & - & 1 & 15 & 15 & - & 6,7 \\
\hline Podsljeme & 17.531 & 10 & 1 & 2 & 11 & 11 & 9,1 & 18,2 \\
\hline Sesvete & 58.416 & 19 & - & - & 19 & 19 & - & - \\
\hline Brezovica & 10.837 & 8 & 3 & 4 & 11 & 11 & 27,3 & 36,4 \\
\hline ZAGREB & & 274 & 9 & 12 & 283 & 271 & 3,2 & 4,4 \\
\hline
\end{tabular}




\section{ILLs share in the City of Zagreb Assembly 2001 and 2005}

\begin{tabular}{|c|c|c|c|}
\hline Elections year & $\begin{array}{c}\text { No. of seats won } \\
\text { by parties }\end{array}$ & $\begin{array}{c}\text { No. of seats won } \\
\text { by ILLs }\end{array}$ & $\begin{array}{c}\text { ILLs share } \\
(\text { total no. of seats } \\
=51) \%\end{array}$ \\
\hline 2001 & 46 & $5(1$ list $)$ & 9,8 \\
\hline 2005 & 44 & $7(2$ lists $)$ & 13,7 \\
\hline
\end{tabular}

INDEPENDENT LOCAL LISTS IN CROATIA:

IN A SEARCH FOR A COMPOSITE THEORETICAL FRAME

\section{Summary}

The paper deals with independent local lists in Croatia, in both analytic and theoretical way. At the beginning, the development and current state of local self-government and local political system in Croatia are described. Data on the independent local lists' participation and success during the 2005 general local elections are presented and analysed. Four theoretical approaches are proposed for an interpretation of the results: system, transition, neo-institutional and democratisation theory. None of them can alone explain the results in a satisfactory manner. That is reason why the author proposes a composite theoretical frame, wbich can explain the role and influence of a broader relevant context on the independent local lists' election success. Certain theoretical bypotheses are generated and to some extent verified in this paper. The advantages of the independent local lists and certain success factors of such lists are identified. Additional theoretical work and empirical verification are needed. Both qualitative insights and quantitative research can be useful.

Key words: independent local lists, local self-government - Croatia, local political system, local elections, composite theoretical frame (system, transition, neo-institutional, democratisation theory) 


\title{
NEZAVISNE LOKALNE LISTE U HRVATSKOJ - U POTRAZI ZA SLOŽENIM TEORIJSKIM OKVIROM
}

\begin{abstract}
Sažetak
U radu se prikazuju, analiziraju i teorijski objašnjavaju podaci o sudjelovanju i uspjebu nezarisnib lokalnib lista na općim lokalnim izborima u Hrvatskoj 2005. No, prije toga se opisuje razvoj i stanje lokalne samouprave $i$ lokalnog politickkog sustava u Hrvatskoj. Rezultati se pokušavaju teorijski objasniti polazeci od cetiriju teorijskib polazišta, teorije sustava, tranzicijske teorije, neoinstitucionalne teorije $i$ teorije demokratizacije. Kako nijedno od tib polazišta ne daje sasvim zadovoljavajuce rezultate, pokušava se oblikovati jedan složeniji teorijski pristup. Razvijene su i provierene odredene teorijske bipoteze. U radu su takoder identificirane dobre strane nezavisnib lokainib lista: one pridonose personalizaciji lokalnib izbora; povećavaju osobnu odgovornost prema biračima; smanjuju napetosti u lokalnoj političkoj zajednici, jer omogućuju biračima da izraze svoje političke stavove i mimo političkih stranaka; olakšavaju duboke lokalne podjele, naročito medunacionalne, tamo gdje ib ima; osiguravaju političku aktimost i u malim lokalnim jedinicama u kojima nacionaine političke stranke nemaju interesa sudjelovati na izborima; dodatno motiviraju birače da izadu na izbore i tako učrršćuju demokratski politički legitimitet; predstavljaju dodatni instrument demokratizacije. Identificirani su i odredeni faktori uspjeba nezavisnib lista na lokalnim izborima, posebno oni koji pripadaju sirem kontekstu u kojem djeluje lokalni politički sustav (postojanje oblika neposredne demokracije; stupanj razvijenosti civilnog društva; stabilnost i uspješnost stranačkog sustava; veličina i priroda lokalnib jedinica; itd.). Za cjeloviti model proučavanja nezavisnib lokalnib lista potrebno je dodatno razvijati teorijski okvir te empirijski provjeravati iz njega izvedene hipoteze. U toj provieri važni su dodatni kvalitatimi uridi i kvantitationa istraživanja.
\end{abstract}

Ključne riječi: nezavisne lokalne liste, lokalna samouprava-Hrvatska, lokalni politički sustav, lokalni izbori, složeni teorijski okvir (teorija sustava, tranzicijska teorija, neo-institucionalna teorija i teorija demokratizacije) 